\title{
Livro didático e cultura da impressão
}

\author{
Didier Dominique Cerqueira Dias de Moraes ${ }^{1}$
}

\section{Resumo}

0 presente trabalho aborda as transformações ocorridas na organização textual-editorial e na configuração gráfico-visual do livro didático na passagem entre dois momentos iniciais de sua história: o da reprodução manuscrita para o do advento da impressão com tipos móveis. A observação de características relativas a esses aspectos em obras canônicas de uso escolar vai revelar diferenças substanciais entre aquelas criadas no período da cultura manuscrita - mesmo considerando as modificações introduzidas em suas edições tipográficas - e aquelas criadas sob a cultura da impressão, incidindo na necessidade de uma primeira precisão e ampliação do conceito de livro didático para além daquele estabelecido pelo mero reconhecimento do uso no espaço da escola como sua característica determinante. 0 livro didático produzido a partir do século XVI será reconhecido como resultado da interação das primeiras formulações da didática moderna com a disseminação de novos processos de reprodução de texto e imagem, trazendo como novidades a subordinação de seu conteúdo a um programa do que deve ser ensinado e à forma como fazê-lo, novas configurações textuais além da simples sequência linear (prosa contínua), o uso de recursos gráficos e a relação entre texto e imagem determinada pela finalidade didática intrínseca a esse artefato impresso. Como consequência, o trabalho aponta para a possibilidade de uma nova precisão da definição do livro didático que também considere as características materiais e de linguagem que o constituem como gênero editorial diferenciado.

\section{Palavras-chave}

Livro didático - Design do livro didático - História da educação.

\section{Textbooks and print culture}

\section{Abstract}

This study addresses the transformations in text rendering and overall editing organization, as well as the changes in the graphic makeup of textbooks, resulting from the transition from scribal reproduction to movable type printing. Observation of

1- Universidade de São Paulo, São Paulo, SP, Brasil. Contato: didier.moraes@usp.br

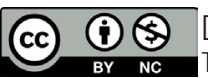


characteristics related to these aspects in canonical works, intended for scholastic use, revealed substantial differences between books produced in the scribal culture periodirrespective of changes arising from the introduction of typographic editions at that time-and works produced in the print culture period. These differences indicated the need for both narrowing and expanding the concept of textbook, so as to overcome the limitations imposed by definitions primarily based on textbook use in the school setting. Textbooks produced from the 16th century onwards were found to be shaped by an interaction between early developments of modern didactics and the dissemination of new processes for text and image reproduction. Novel features emerging from this interaction included the subordination of contents to a program to be taught, as well as to the manner these contents should be taught; new text configurations, not limited to simple linear sequences (continuous prose); use of graphic resources; and an interaction between text and image guided by didactic purposes intrinsic to this printed product. The investigation points to the possibility of achieving unprecedented precision in redefining the concept of textbook-one also taking into account the material and graphic characteristics which typify this product as a specific editorial genre.

\section{Keywords}

Textbooks - Textbook design - History of education.

\section{O livro didático da era do manuscrito}

"O livro didático talvez seja uma das modalidades mais antigas de expressão escrita, já que é uma das condições para o funcionamento da escola”, afırmam as pesquisadoras Marisa Lajolo e Regina Zilberman (1999, p. 120). Como exemplo a corroborar a tese, as autoras apresentam Poética, obra escrita por Aristóteles no século IV a.C. na forma de anotações para uso em suas aulas, como um ancestral ilustre do gênero. Assim, essas anotações teriam sido produzidas originalmente como guia para transmissão oral - ou seja, um instrumento usado pelo mestre na preparação de suas aulas -, e não para serem lidas pelos alunos em estudo individual, embora sua reprodução posterior levou naturalmente a esse segundo uso e também à sua utilização como obra teórica autônoma em relação ao uso escolar.

Mesmo com a ressalva de que não se pode dotar um sentido único e historicamente permanente para a palavra escola - como aquela utilizada para designar o espaço definido socialmente para transmissão e aquisição de conhecimentos, envolvendo a relação entre mestre e alunos - e de que tal espaço, tal relação, tais práticas, tal organização e tal finalidade nunca foram idênticos ao longo do tempo (VINCENT; LAHIRE; THIN, 2001), parece-nos apropriada a condição de ancestralidade do livro didático atribuída pelas autoras a essa obra.

Há diversos manuscritos medievais de Poética em grego, na forma de códices, que chegaram ao nosso tempo (LOBEL, 2006), mas nenhum está disponível como arquivo 
digital, nas bibliotecas que os acolhem, para consulta à distância e reprodução livre. 0 único que pode ser visualizado, mas não reproduzido, é um códice do século XVI conservado na Biblioteca do Vaticano, ${ }^{2}$ que apresenta a organização visual mais comum dos livros copiados manualmente para a finalidade de estudo, ou seja, a configuração de texto linear, sem quebras de parágrafo, intervalos para títulos e uso de cor.

Não se obtiveram, igualmente, imagens do volume específico de Poética feito pelo editor e impressor veneziano Aldo Manuzio, que produziu uma edição princeps em grego da obra completa de Aristóteles em cinco volumes entre 1495 e 1498, mas outras edições posteriores nessa língua apresentam organização visual próxima das reproduções manuscritas para estudo (figura 1). Já as edições que se seguiram, contendo tradução e comentários, apresentavam recursos tipográficos para organização e diferenciação das partes especializadas do conteúdo, o que indicava sua utilização mais propriamente didática (figura 2).

Figura 1 - Aristóteles. De Arte Poetica. Florença: Petro Victorio, 1564. Edição integral, em grego, sem acréscimos e comentários

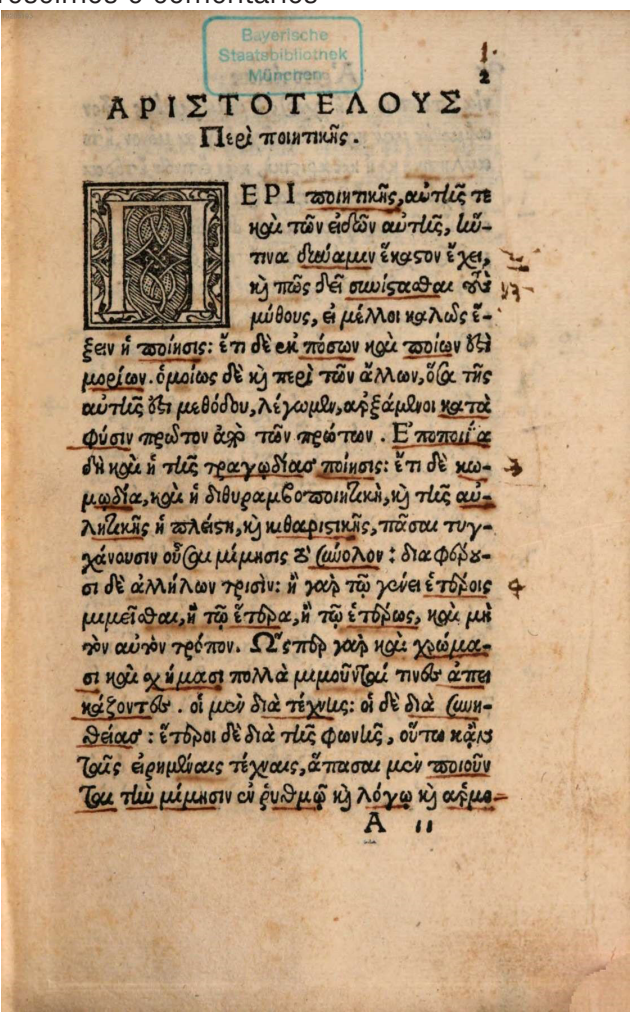

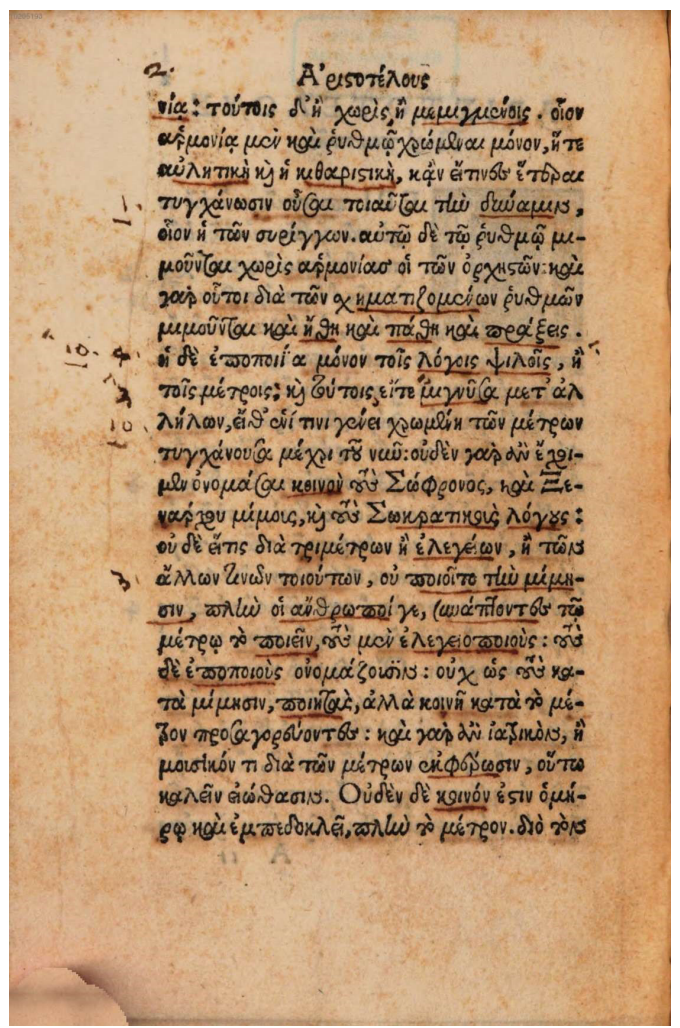

Fonte: Bayerische Staatsbibliothek München, urn=urn:nbn:de:bvb:12-bsb10205193-8. Reprodução permitida para uso não comercial.

2- Disponível em: <http://digi.vatlib.it/view/MSS_Vat.gr.1904.pt.2>. 
Figura 2 - Aristóteles; Lodovico Castelvetro. La Poetica d'Aristotile. Basilea: Pietro de Sedabonis, 1576. Edição em italiano, com interpretação e explicações do tradutor, para uso facilitado
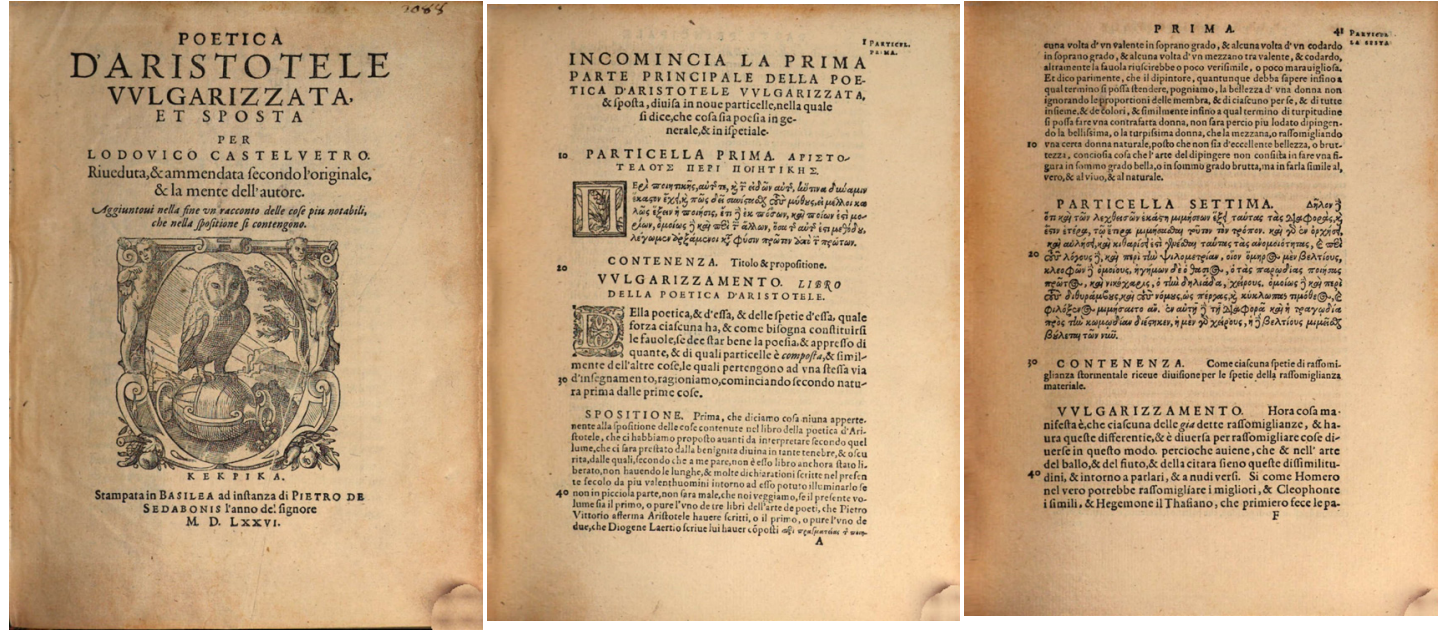

Fonte: Bayerische Staatsbibliothek München, urn:nbn:de:bvb:12-bsb10981043-3. Reprodução permitida para uso não comercial.

Outra obra citada pelas autoras, Institutio Oratoria, de Marcus Fabius Quintilianus, do século I d.C., preencheria também a condição de obra didática escrita muito antes da invenção da imprensa com tipos móveis, ao trazer lições de retórica, excertos e comentários de autores gregos e latinos para uso escolar (LAJOLO; ZILBERMAN, 1999). Durante os primeiros cinco séculos desde sua escrita, teve grande influência entre eruditos e foi utilizada em cursos de retórica em Roma, permanecendo relativamente esquecida no intervalo entre os séculos VI e XV - com um breve reconhecimento no norte da França no século XII, baseado em fragmentos que circulavam -, até a descoberta de um manuscrito completo na Abadia de St. Gallen, que ensejou novas cópias e edições tipográficas em pleno renascimento da cultura clássica (HONEYCUTT, 2007). 0 códice aqui reproduzido, datado de fins do século XV e com ricas iluminuras, apresenta títulos dos assuntos tratados, com uso de cor, e capitulares marcando claramente o início dessas seções e facilitando sua localização (figura 3). Mas são as edições impressas em tipografia que fazem mais evidente a finalidade didática da obra, a partir de uma organização visual diferenciada e da utilização de recursos editoriais e tipográficos especiais (fıgura 4).

Como ancestral igualmente ilustre do livro didático, pode-se certamente incluir Os elementos, obra escrita pelo filósofo possivelmente grego Euclides, que viveu em Alexandria entre os séculos IV e III a.C. Essa obra, constituída de 13 livros, é um dos mais antigos tratados científicos conhecidos e teve uso escolar no ensino da matemática e da geometria desde a Antiguidade até pelo menos o século XIX. A quantidade de manuscritos antigos e medievais preservados e o número de edições tipográficas atesta sua importância e sua popularidade. Pelo método de sistematização e exposição de seu conteúdo, apoiado em sequências de imagens para efetivar as demonstrações e ensinar, tem não só caráter de obra científica como de obra didática, em que texto e imagem se complementam e nenhum pode ser omitido sem comprometimento da informação. Assim se poderia dizer que $O s$ 
elementos é também uma obra precursora do caráter multimodal que parte significativa dos livros escolares assumirá muitos séculos mais tarde (figuras 5, 6 e 7).

Figura 3 - Marcus Fabius Quintilianus (século I d.C.). De institutione oratoria. Manuscrito de Nápoles, de 1482
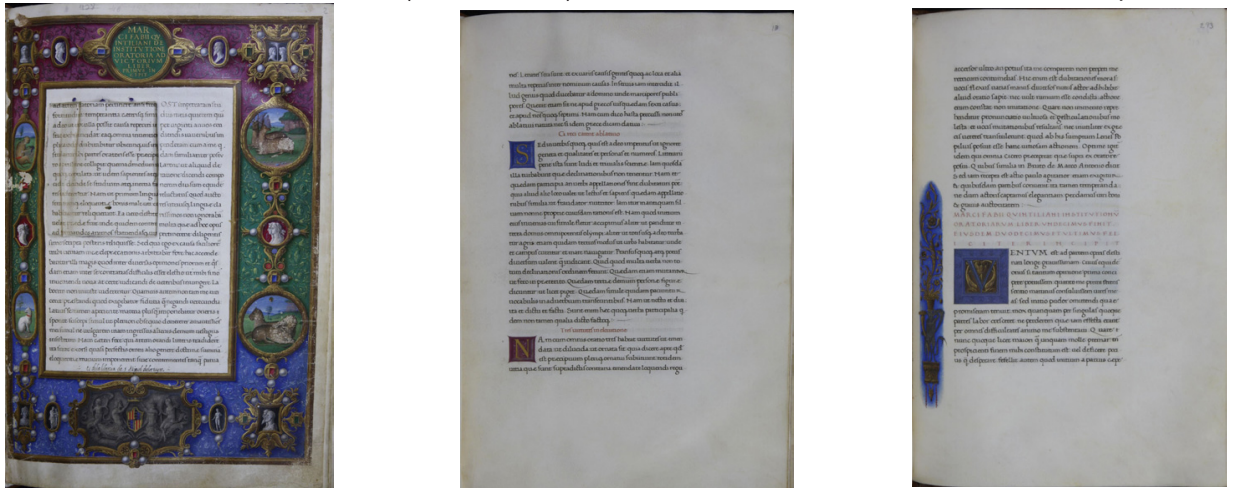

Fonte: Biblioteca da Universitat de València, n. reg. b1890283. Reprodução permitida para uso não comercial

Figura 4 - Marcus Fabius Quintilianus (século I d.C). Oratoriarum institutionum libri duodecim, s.l., 1516. Edição que inclui facilidades para consulta e utilização didática, como índice alfabético, comentários, referências laterais e variação tipográfica que inclui uso de letras góticas e latinas
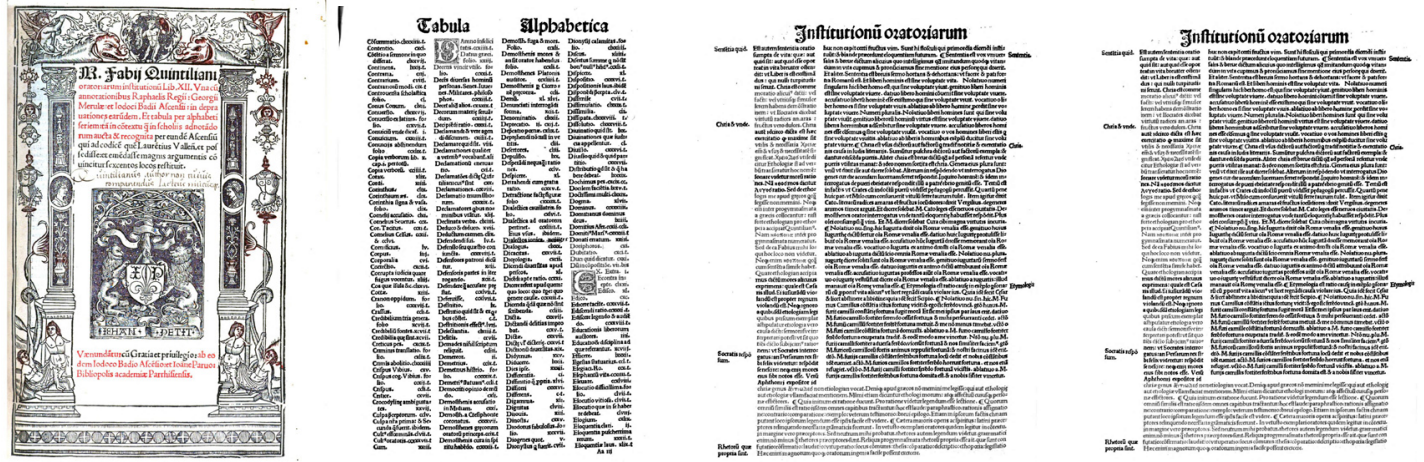

Fonte: Bayerische Staatsbibliothek München, urn:nbn:de:bvb:12-bsb10140826-7. Reprodução permitida para uso não comercial.

Figura 5 - Euclides. Elementa. Códice do século XIII em grego antigo, em pergaminho

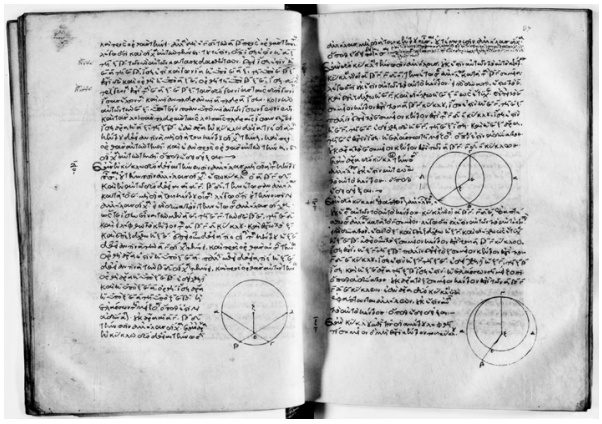

Fonte: Bibliothèque National de France, ark:/12148/btv1b11000284r. Reprodução permitida para uso não comercial. 
Figura 6 - Euclides. Elementa, liber 1. Edição em grego de Argentoratum (Strasbourg), 1538
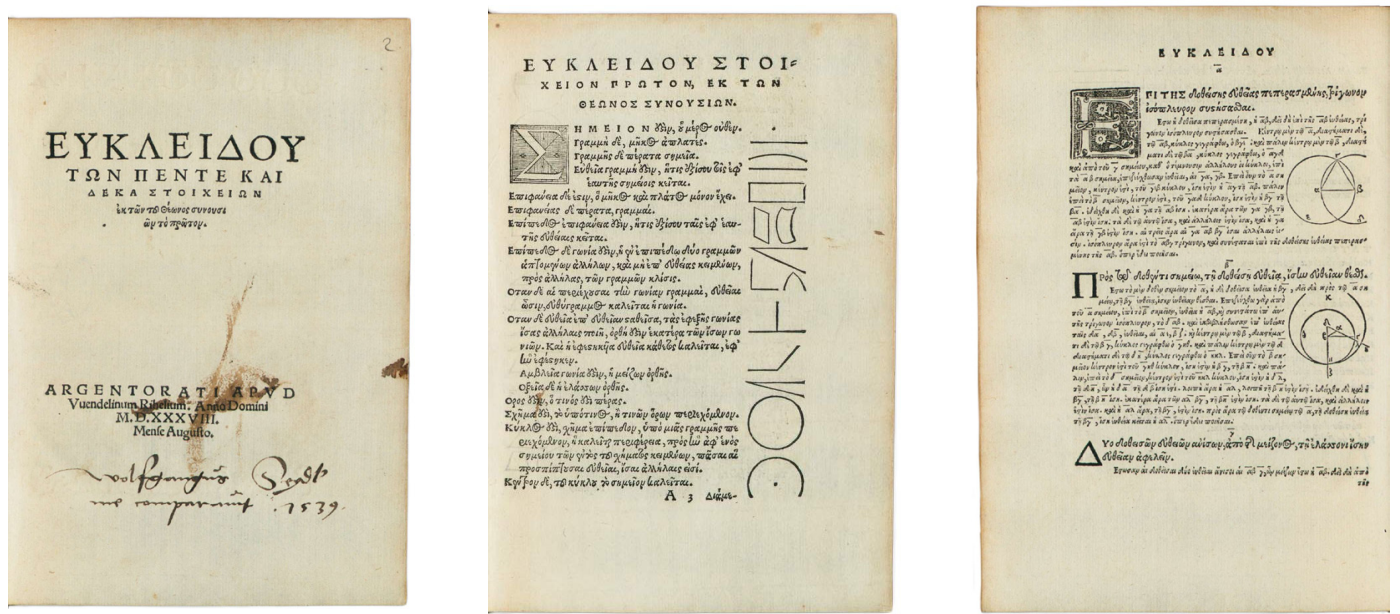

Fonte: Bayerische Staatsbibliothek München, VD16 E 4143, urn:nbn:de:bvb:12-bsb00076066-2. Reprodução permitida para uso não comercial.

Figura 7 - The first six books of The Elements of Euclid, London, William Pickering, 1847. Adaptação de Oliver Byrne, que utiliza a cor como recurso didático
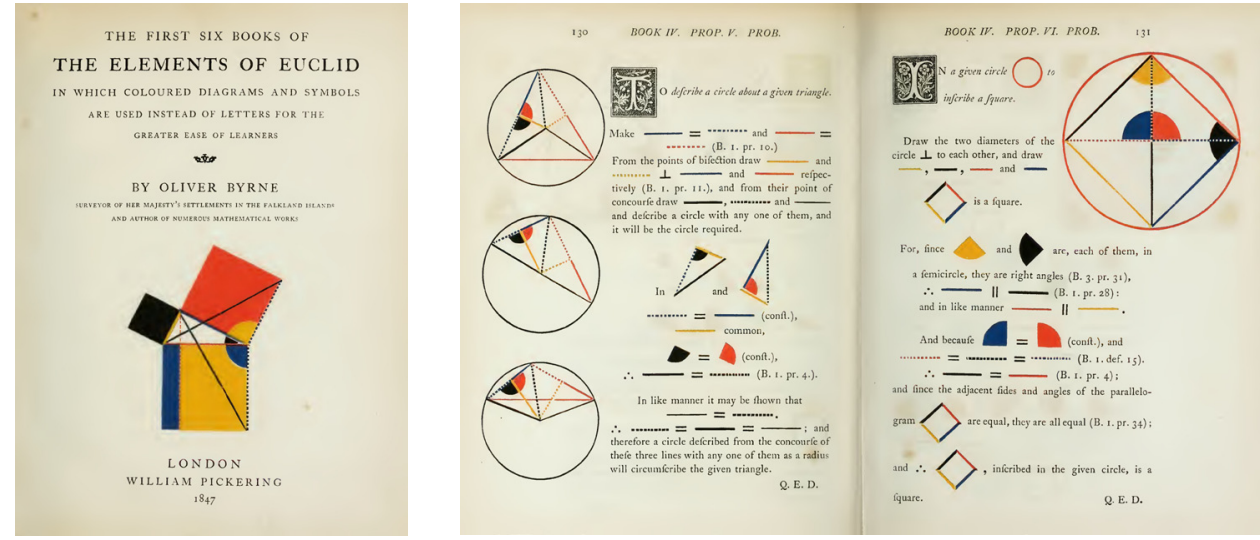

Fonte: Internet Archive/Unesco, University of Toronto, Thomas Fisher Rare Book Library, AHH-8373. Public Domain. Reprodução permitida para uso não comercial.

Ainda no período da cultura manuscrita, circularam na Idade Média os chamados Donatos, tratados de gramática latina elementar para uso escolar que tinham origem em obra mais ampla de Aelius Donatus (século IV d.C.), a Ars Grammatica. Esses Donatos, geralmente partes ou adaptações de partes da obra original, ganharam edições impressas em xilogravura, portanto anteriormente ao uso de tipos móveis, feitas provavelmente nos Países Baixos e em território da atual Alemanha. Segundo Wilson Martins (2002), tiveram uso tão generalizado, que a palavra donatos foi estendida, por analogia, a outros livros escolares. Com a invenção dos tipos móveis, foram, junto com a Bíblia, os primeiros livros a serem impressos, "em número prodigioso de edições" (SILVA, 1922, p. 7), podendo ser 
considerados livros didáticos não apenas pelo uso na escola, mas também sob a acepção particular de constituírem uma adaptação para finalidade didática ou uma transposição do saber acadêmico para o saber escolar (BITTENCOURT, 1993) (Figuras 8 e 9).

0 confronto entre edições manuscritas e edições impressas tipograficamente de algumas das obras apresentadas mostrou como, no segundo caso, transformações editoriais e formais substanciais - utilizando recursos próprios do novo meio de reprodução, mas também respondendo a novas necessidades e transformações do ensino, como será visto adiante - foram introduzidas para torná-las efetivamente mais apropriadas ao uso escolar, em outras palavras, mais didáticas. Assim, uma dimensão material e visual particularizadora dos livros destinados ao uso escolar como um gênero diferenciado vai se tornando mais evidente após o surgimento da impressão com tipos móveis.

Figura 8 - Páginas de Donatos (gramáticas latinas escolares). À esquerda: edição manuscrita do século IX. Nas margens, anotações de usuário ou copista. À direita: Aelius Donatus. Ars minor (parte da Ars Gramatica), 1475?. Edição xilográfica em alemão
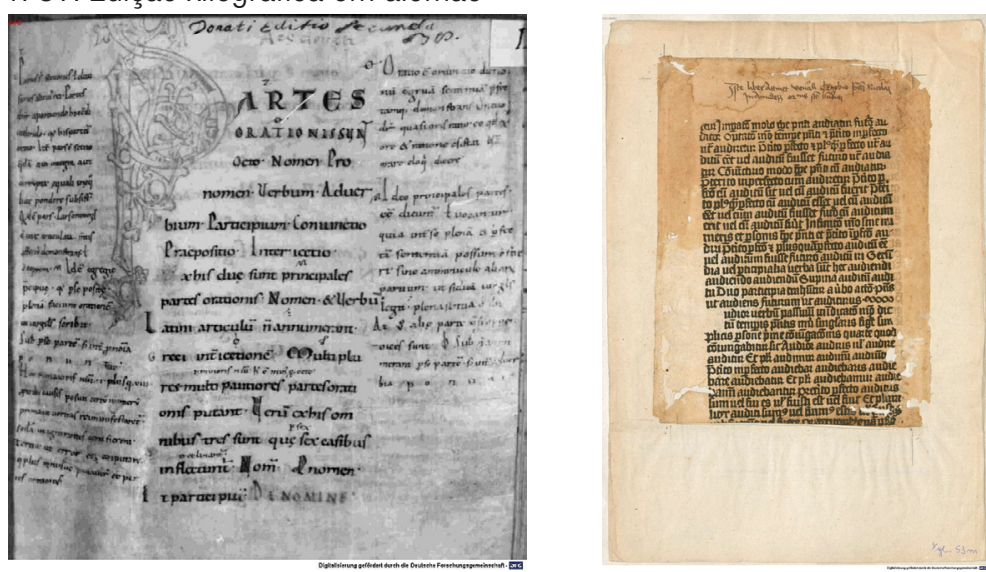

Fonte: Bayerische Staatsbibliothek München, Clm 14737, urn:nbn:de:bvb:12-bsb00012921-8 e urn:nbn:de:bvb:12-bsb00038682-3. Reprodução permitida para uso não comercial.

Figura 9 - Aelius Donatus. Ars minor. Augsburg, 1497. A gravura do frontispício e a exposição em alemão composta em corpo menor sobre a linha em latim composta em corpo maior atestam o uso escolar da edição
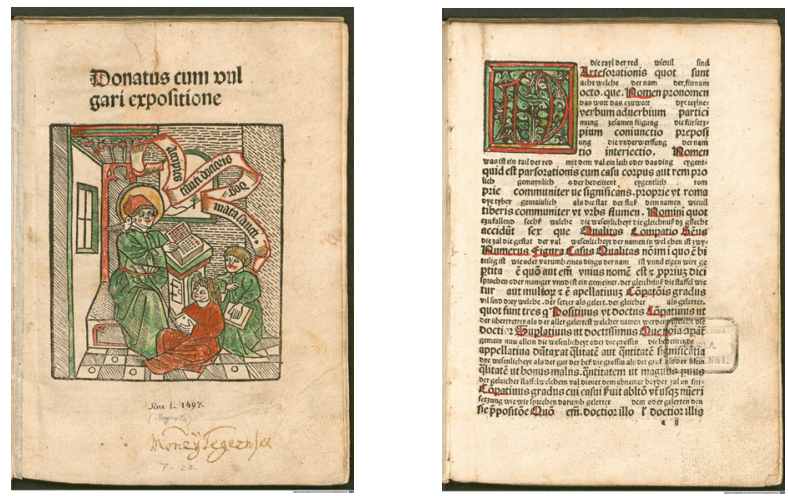

Fonte: Bayerische Staatsbibliothek München, Ink D-266 GW 8982, urn:nbn:de:bvb:12-bsb00026765-8. Reprodução permitida para uso não comercial. 


\section{Livros didáticos da era da impressão}

As obras até agora apresentadas como livros didáticos o foram basicamente sob uma acepção que tem como núcleo definidor a utilização na escola, entendida de forma genérica como o espaço específico para a aprendizagem envolvendo mestre e alunos, complementada ou não por outras características, como o uso como roteiro pelo professor, a relação do texto com as imagens ou a adaptação de um conteúdo não originalmente escolar para essa nova finalidade.

Sem deixar de admitir que todas as obras mencionadas foram, a seu modo e em seu tempo, livros didáticos, as transformações do ensino e da escola e a disseminação da tipografia ocorridas no século XVI vão resultar em toda uma nova produção livreira destinada à escola com características bastante diversas da anterior, mesmo em suas versões impressas tipograficamente, que obrigam a uma ampliação da definição de livro didático para além do uso exclusivamente na escola.

Esse novo livro escolar, com características definidoras básicas presentes nos livros didáticos que utilizamos hoje, segundo Walter Ong (2002), surge com Petrus Ramus, no terceiro quarto do século XVI, não apenas pelo uso ligado à escola, mas também pela definição do tipo de conhecimento abordado e pela forma mesma de fazê-lo:

[...] manuais para virtualmente todas as disciplinas (dialética ou lógica, retórica, gramática, aritmética, etc.) que provinham de definições peremptórias e divisões principais conduzindo a outras definições e mais divisões, até que cada última partícula do assunto fosse dissecada e eliminada. Um livro ramista sobre um determinado assunto não estabelecia nenhum intercâmbio com qualquer coisa fora dele mesmo. Nem mesmo dificuldades ou "adversários" apareciam. Um assunto curricular ou "art" [disciplina], se apropriadamente apresentado conforme o método ramista, não envolvia nenhuma dificuldade (segundo sustentavam os ramistas): se você definia e dividia de modo apropriado, tudo na disciplina seria autoevidente e a disciplina, ela mesma, seria completa e autônoma. Ramus relegava as dificuldades e refutações a adversários a palestras separadas (scholae) sobre dialética, retórica, gramática, aritmética e todo o resto. (ONG, 2002, p. 131-132, tradução minha).

Petrus Ramus (Pierre De La Ramée, 1515-1572) foi figura proeminente da chamada virada instrucional ocorrida no século XVI como reação ao ensino modelado pela escolástica medieval. Segundo David Hamilton, Ramus lançou as bases da didática moderna, ao estabelecer currículos - um quadro fechado dos conhecimentos a serem ensinados, o que não ocorria até então - e um método de ensino, prosseguindo o trabalho de Lorenzo Valla (1407-1457) e Rudolphus Agricola (1444-1486), de transformação da dialética (arte da argumentação) em didática (arte do ensino) (HAMILTON, 2003). A consequência prática foi a própria organização dos assuntos das chamadas artes em configurações gráficas que relacionavam os conteúdos a serem ensinados, apresentadas nas obras que divulgavam seus escritos, como também a edição de obras didáticas dedicadas a várias dessas artes, que também reproduziam esquemas de conhecimentos específicos para facilitar sua consulta e memorização (figuras 10, 11, 12 e 13). 
Figura 10 - Petrus Ramus. Professio Regia: Septem artes liberales.... Basilea, 1576. Rosto, página inicial com esquema do conteúdo geral do livro e página com esquemas dos assuntos específicos
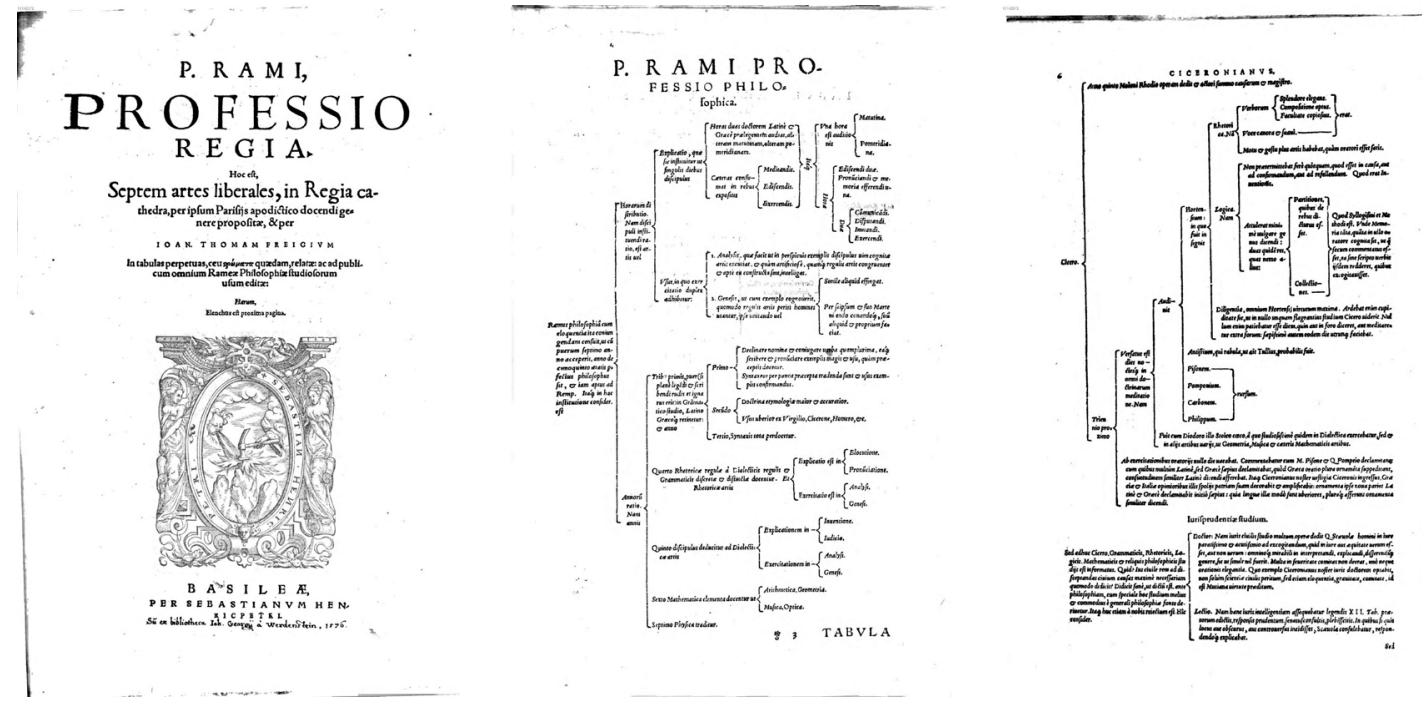

Fonte: Bayerische Staatsbibliothek München, VD16 L 529, urn:nbn:de:bvb:12-bsb10142572-7. Reprodução permitida para uso não comercial.

Figura 11 - Petrus Ramus. Arithmetica. Paris, 1562. Note-se a composição de formas matriciais, composição em blocos e uso de itálico como contraste tipográfico

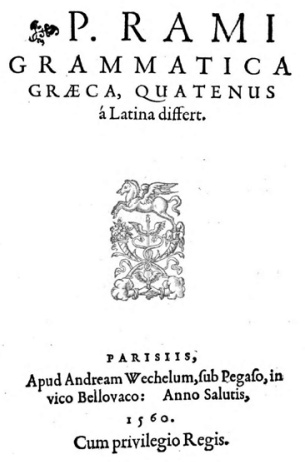

$\operatorname{lom}_{i \rightarrow \infty}$ P. R A M I

G R A M A T I C A áLatina differt.

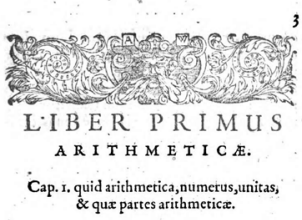

x. A Rith metica est doctitiAnabene numerandi.

2. Numerus est ex unitatibus colle $=$ ita multitudo: 2: d. 7 .

- Ut binarius numerus eft collectus ex uno \& $^{\circ}$ uno, ternarius ex uno \&uno \&uno,quaternarius nümerus eft ex unitarabus colleats nultritudo. 3. Linitas est fecundum quam unumquodque unum dicitur. 1.d. 7 .

quodque undeus, unus mundus, unus Rex.

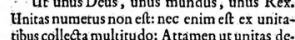
finitur, fecundúm quam unumquodoue unum

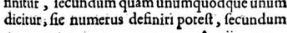

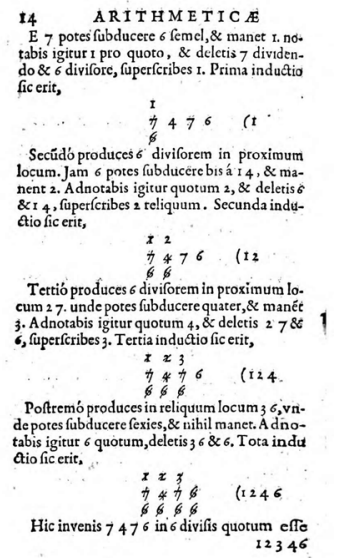

12346

Fonte: Bayerische Staatsbibliothek, urn:nbn:de:bvb:12-bsb10186745-7. Reprodução permitida para uso não comercial. 
Figura 12 - Petrus Ramus. Grammatica graeca quatenus a lat. differt., Paris, 1560. Uso de itálico e variação de corpos como contraste tipográfico com finalidade diferenciadora

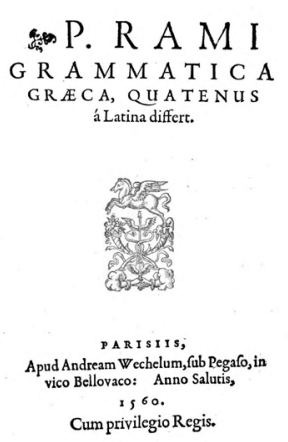

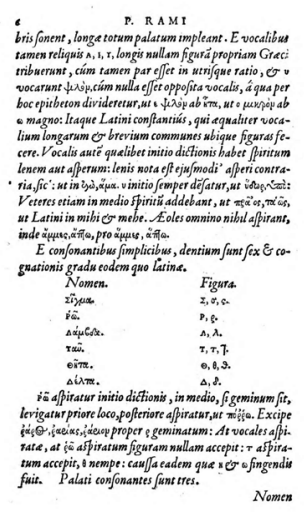

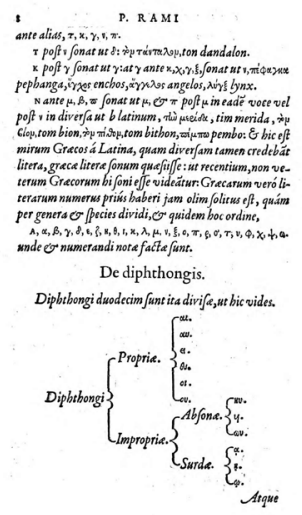

Fonte: Bayerische Staatsbibliothek, urn:nbn:de:bvb:12-bsb10162747-8. Reprodução permitida para uso não comercial.

Figura 13 - P. De La Ramée (Petrus Ramus). Grammaire, Paris, 1572. Páginas com leiautes e tipografia diferenciados conforme a função do texto

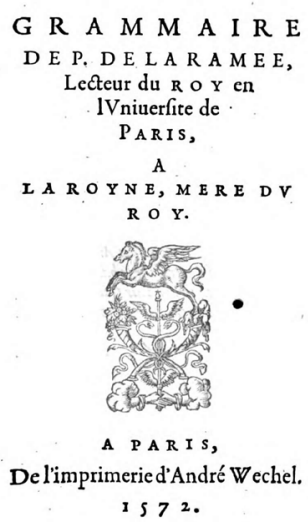

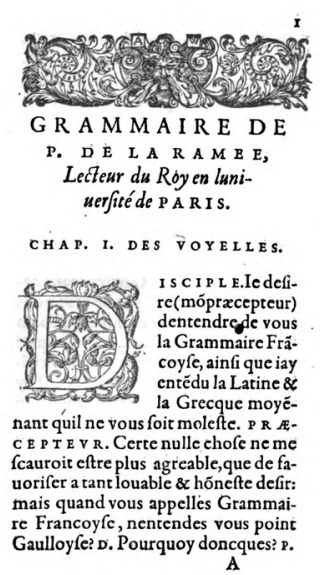

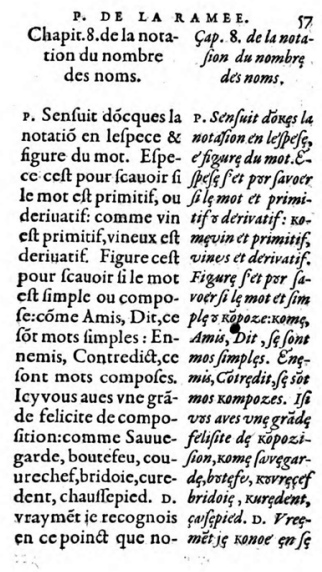

Fonte: Bayerische Staatsbibliothek, urn:nbn:de:bvb:12-bsb10185562-6. Reprodução permitida para uso não comercial.

Em sua obra capital sobre Ramus, Ong (1983) identifica a origem e a evolução do ramismo como um epifenômeno do desenvolvimento da cultura humanista e dedica especial atenção às relações entre o pensamento ramista e a invenção e o desenvolvimento inicial da impressão com tipos móveis. 
Neste contexto, "método" alcança verdadeiramente definição e forma final à medida que o interior dos próprios livros de Ramus tornam-se espacialmente mais bem organizados, numa época em que os impressores foram se liberando da tradição manuscrita e foram aprendendo que a configuração de um impresso envolvia um compromisso radicalmente diferente com o espaço que o formato de um manuscrito. [...].

Nos próprios trabalhos de Ramus, a evolução é completa do período do incunábulo ou próximo ao incunábulo, estágio quase manuscrito da tipografia, no qual um livro poderia ser assimilado apenas sendo lido (entendido também como sendo lido em voz alta), até o estágio tipográfico definitivo, quando um livro poderia ser - ao menos em parte - assimilado pelo percurso do olhar. No caso de Ramus, é evidente que o senso de estrutura no interior de uma disciplina e no interior do próprio discurso desenvolveu-se em conexão com as transformações no trabalho que já haviam ocorrido na imprensa. (ONG, 1983, p. 307 e 311, tradução minha).

Ong define o surgimento desse tipo de livro didático como uma consequência das transformações no pensamento e na cultura ocidental decorrentes do surgimento da impressão, como o foram a transformação do Renascimento italiano num movimento europeu, o surgimento e a difusão da Reforma protestante e o próprio surgimento da ciência moderna, relacionados por Elizabeth Eisenstein (1980) como as três mais importantes consequências do surgimento da imprensa. Assim, em contraposição a características de escrita vigentes no período da cultura do manuscrito, Ong (2002, p. 129, tradução minha) aponta:

A impressão estimula um sentimento de conclusão, uma sensação de que o que foi encontrado em um texto foi finalizado, atingiu um estado de acabamento. Essa sensação afeta a criação literária e isto afeta a análise filosófica ou o trabalho científico.

[...] A impressão, do mesmo modo, situa elocução e pensamento em uma superfície desimpedida de tudo o mais, mas também vai mais longe ao sugerir autocontenção. A impressão encerra o pensamento em milhares de cópias de uma obra com exatamente a mesma consistência visual e física.

Essas características estão presentes nos livros que Ramus escreveu, que constituíram um modelo recorrente aos manuais escolares produzidos pelo menos até o século XVII. Assim, não só por coincidência temporal, o surgimento do livro didático moderno está organicamente ligado ao surgimento da própria cultura da impressão, de suas características e das transformações de mentalidade relacionadas a uma modalidade de produção textual diferente da manuscrita.

Considerando que a escrita lança a palavra originalmente falada num espaço visual, e que a impressão o faz de maneira definitiva, criando um espaço tipográfico abstrato, Ong examina a transformação de algumas formas já existentes no livro manuscrito e o surgimento de novas formas próprias da impressão tipográfica, como índices de assunto, índices alfabéticos, titulagens, reprodução de imagens em relação a palavras - como já é possivel observar nas edições impressas de obras didáticas provenientes da cultura do manuscrito. Além disso, o autor atesta que, "cedo na era da impressão, gráficos extremamente complexos aparecem no ensino de assuntos acadêmicos" (ONG, 2002, p. 126, tradução minha). 
No caso dos esquemas didáticos de Ramus, Hamilton (1990) chega a citá-los explicitamente como tendo sido beneficiados pela nova tecnologia da impressão por tipos móveis e estabelece uma relação entre as novas ideias pedagógicas, o design e a proliferação dos livros escolares:

Para concluir, propus que o design e a organização de textos instrucionais devem muito ao pressuposto - originado de Aristóteles - de que o conhecimento pode ser mapeado e ordenado de acordo com a "natureza”. Além disso, também sugeri que este pressuposto não apenas sustentou o design do livro didático, como foi fundamental para o surgimento do currículo e do pensamento pedagógico. Na verdade, eu mesmo iria tão longe a ponto de propor que, nesses termos, o século XVII foi a era de ouro dos livros didáticos, dos currículos e da didática. (HAMILTON, 1990, s/p, tradução minha).

\section{Livros para estudo e livros para instrução}

Apoiando-se nessa reflexão histórica, é possível agora estabelecer uma diferença significativa entre os ancestrais dos livros didáticos e o que seriam livros didáticos propriamente ditos. Os primeiros, que, como vimos, existiriam pelo menos desde Poética, de Aristóteles, seriam livros para estudo realizado solitariamente ou mesmo em grupo ou até em aulas nas academias da Antiguidade e nas universidades medievais. Os últimos já seriam livros para instrução, os quais só teriam surgido com a virada instrucional do século XVI, o ramismo e as primeiras formulações da didática e dos currículos:

Talvez o problema conceitual fundamental seja encontrar um modo de distinguir manuais [livros didáticos] de livros escolares. Não surpreendentemente, minha posição é de que livros didáticos refletem visivelmente considerações pedagógicas. Isto é, um livro didático não é apenas um livro usado em escolas. Ao contrário, é um livro que foi conscientemente concebido e organizado para servir aos fins da educação escolar.

Nesta medida, então, livros didáticos estão organicamente ligados às novas circunstâncias da educação escolar. [...] Minha tese é que livros didáticos têm sua origem nos séculos XVI e XVII. (HAMILTON, 1990, s/p, tradução minha).

E esses livros para educação escolar foram desde o início conformados com a participação decisiva do surgimento da impressão com tipos móveis:

No entanto, mesmo esses desenvolvimentos foram prenunciados pelas primeiras mudanças no leiaute de livros [...] e na posterior organização de dicionários, compêndios, bibliografias e enciclopédias dos séculos XV e XVI [...]. Na verdade, muitas dessas primeiras mudanças na organização dos livros não se destinavam a atender a objetivos pedagógicos. Em vez disso, pretendiam fazer com que os textos fossem mais acessiveis a seus possuidores/usuários habituais (por exemplo, pregadores). (HAMILTON, 1990, s/p, tradição minha). 
Também é possivel agora falar com maior propriedade, e sem risco de cometer anacronismo histórico, sobre a associação entre livro didático e escola, na medida em que essa forma social, tal como a conhecemos hoje, está em gestação exatamente nesse período. É na segunda metade do século XVII que algumas sociedades europeias verão o surgimento de espaços concebidos e organizados para abrigar uma nova relação entre mestre e aluno, não mais de caráter particular e sim conforme regras impessoais definindo papéis e deveres, a que se pode chamar de relação pedagógica, e com tempo estipulado em termos do dia, do ano e da vida para se desenvolver (VINCENT; LAHIRE; THIN, 2001). Ao espaço e ao tempo escolares somam-se as disciplinas e esse novo livro "conscientemente concebido e organizado para servir aos fins da educação escolar", tal como referido por Hamilton (1990, s/p), a compor essa forma social particular, a escola, que a partir daí sofrerá contínuas transformações, mas que, em seus traços essenciais, está constituída no final do século XVII, como decorrência da instauração de uma nova ordem pública que caracterizou o processo sócio-histórico de formação dos Estados modernos (VINCENT; LAHIRE; THIN, 2001).

\section{As configurações gráficas dos livros didáticos da virada instrucional e da era da impressão}

Com as transformações de leiaute mencionadas, desde seu início, o livro didático surgido com a virada instrucional apresenta outras configurações gráficas além da que Michael Twyman (1986) chama de configuração linear interrompida (linear-interrupted configuration), ou seja, o texto composto como prosa contínua, majoritário nas obras manuscritas. Este é o equivalente mais próximo em comunicação gráfıca da linearidade temporal do discurso, em que as quebras nas extremidades de linhas são interrupções arbitrárias sem relação com a sintaxe ou a semântica. Já os livros didáticos impressos desde cedo apresentavam listas, matrizes ou tabelas e ramificações, além do uso de imagens com finalidade não decorativa, variações de desenho e tamanho dos caracteres e, mais raramente, emprego de cores, como necessidades decorrentes do seu propósito didático.

0 autor apoia a sua análise da evolução da linguagem gráfica numa distinção entre dois tipos de características que ela apresenta, às quais denomina intrínsecas e extrínsecas:

Por intrínsecas se entendem aquelas características que residem nos caracteres ou sinais próprios e no sistema que é usado para produzi-los. Características intrínsecas incluem a gama de caracteres disponiveis (o que diferentes especialistas podem chamar alfabeto, fonte, ou conjunto de caracteres), as variantes desses caracteres (como letras maiúsculas, minúsculas, itálicos e negritos), o estilo dos caracteres (tipo e estilo de escrita ou letras) e o tamanho. [...].

Características extrínsecas incluem as configurações de linguagem gráfica. Quatro delas têm sido convencionalmente usadas graficamente na organização de palavras e números: interrupção linear (prosa contínua), lista, matriz e configurações de ramificação. Outras características extrínsecas são espaciais em um sentido mais limitado e se relacionam com a organização de unidades linguísticas dentro de uma determinada configuração. No nível micro, o uso do espaço inclui ajustes finos, tais como o espaçamento das letras e o posicionamento no eixo vertical de caracteres superiores e inferiores. No nível macro, inclui espaçamento entre palavras, 
espaçamento entre linhas e espaçamento de unidades maiores de informações, do tipo discutido por muitos autores sobre tipografia. (TWYMAN, 1986, p. 190-191, tradução minha).

Assim, o autor apresenta a evolução e o acréscimo de recursos oferecidos pelas duas características da linguagem gráfica a partir das necessidades de comunicação impressa dos diversos tipos de conteúdo produzidos ao longo dos séculos. Começa mencionando a unificação dos alfabetos romano e uncial na criação de um único alfabeto constituído por maiúsculas e minúsculas, passa pela incorporação do itálico e do negrito - que existiam como fontes independentes, com desenho próprio - , do versalete etc. como variações tipográficas de uma mesma fonte, e mostra as transformações no uso e na organização do espaço da página, da cor etc., destacando particularmente as necessidades dos textos científicos e de uso escolar, mostrando a íntima relação destes com a cultura da impressão. Em um trabalho específico (TWYMAN, 1990), mostrará a utilização de variações tipográficas (características intrínsecas), particularmente do negrito (bold), em quadros e tabelas cronológicas de história, impressos que se disseminaram na Inglaterra nos séculos XVIII e XIX, como passo para sua posterior adoção em livros didáticos como recurso de atração visual com finalidade pedagógica de induzir a memorização.

\section{As imagens no livro didático: a obra precursora de Comenius}

0 uso de imagens com finalidade didática é outra característica dos livros escolares que surge bastante precocemente, impondo exigências técnicas à atividade impressora num tempo em que a combinação de texto e imagem obrigava à impressão separada de tipografia e xilografia ou gravura em metal, ou a reunião dessas diferentes matrizes para impressão simultânea. A obra de Jan Amos Comenius (1592-1670), Orbis Sensualium Pictus (O mundo sensivel em imagens), de 1658, para o ensino de diversos conteúdos simultaneamente ao ensino do latim e do vernáculo (alemão), traz composição tipográfica com combinação de tipos góticos e latinos, em romano e itálico, e ilustração gravada em metal com números sobre ela (figura 14).

A concepção desse livro expressa a relação direta e explícita entre a nova arte da didática, a transformação da escola e do ensino e a cultura gráfica. Jan Amos Comenius completa o processo iniciado com a virada instrucional, ao instituir a didática moderna com sua ação pedagógica e sua obra Didática Magna: tratado universal de ensinar tudo a todos, publicada em 1679. Nessa obra, a partir de uma crítica radical à escola e aos métodos vigentes, Comenius propõe uma reforma profunda do ensino e uma nova organização escolar por graus etários, com princípios pedagógicos, currículos correspondentes, métodos específicos para cada disciplina (línguas, ciências, artes) e qualidades (moral, piedade), normas de funcionamento escolar, universalização da educação sem distinção de classe e sexo, constituindo um edifício teórico da educação não superado até hoje em seus aspectos essenciais. E, no que nos interessa mais de perto, define como um dos principais meios - incontornável, na verdade - o uso de um único livro exclusivo para o nível elementar e de livros próprios para cada disciplina nos níveis subsequentes, com as seguintes características gerais: 
III. Sejam feitos com primor e escritos em linguagem acessivel.

33. Estes livros, portanto, deverão ser conformes às nossas leis da facilidade, da solidez e da brevidade, e contar, para todas as escolas, tudo o que é necessário, de modo completo, sólido e aprimorado, para que sejam uma imagem verdadeira de todo o universo (o qual deve ser impresso nas mentes juvenis). E (o que vivamente desejo e inculco) que esses livros exponham todas as coisas de modo familiar e popular, para que tornem tudo acessível aos alunos, de modo que o entendam por si, mesmo sem qualquer professor. [...].

34. Gostaria que esses livros fossem compostos em forma de diálogo [...], porque, dessa maneira, mais facilmente se pode adaptar a matéria e o estilo aos espíritos juvenis, para que não imaginem que as coisas são, para eles, ou impossíveis ou árduas ou demasiado difíceis [...]. (COMENIUS, 2001, cap. XIX).

Figura 14 - Johann Amos Comenius. Orbis Sensualium Pictus (0 mundo sensível em imagens, 1658), Nuremberg, 1664. Uso de tipos romanos e góticos como principal contraste tipográfico com finalidade didática
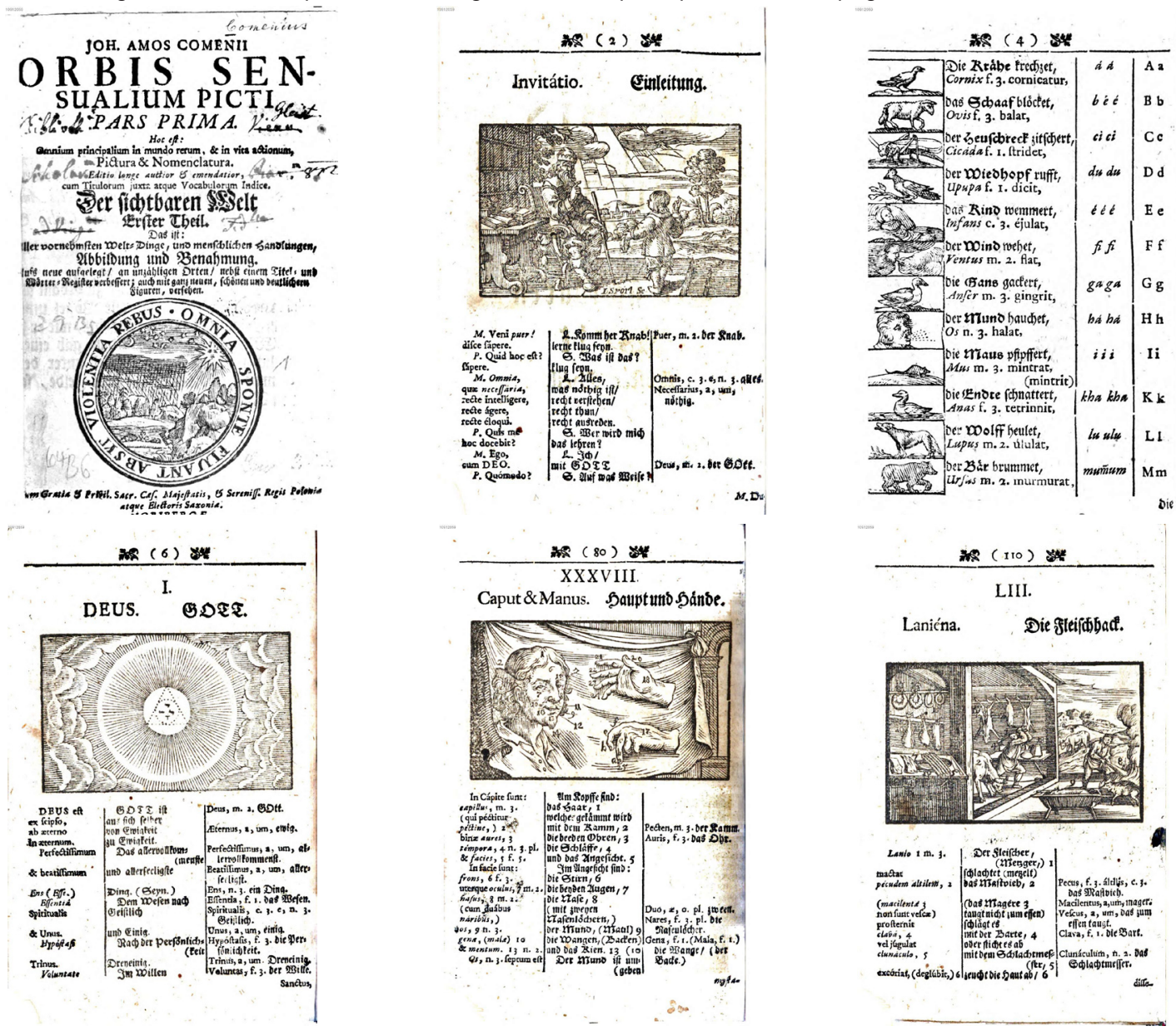

Fonte: Internet Archive/Unesco. Public Domain. Reprodução permitida para uso não comercial. 
No caso do primeiro grau, a escola materna, ele mesmo se ocupou da escrita do livro, seguindo estes princípios e recomendações:

II. 0 exercitador dos sentidos.

25. Outra coisa que poderá ser útil aos exercícios da escola materna será um Livrinho de Imagens, a colocar nas mãos das próprias crianças. Com efeito, como nesta escola se deve sobretudo exercitar os sentidos a receber as impressões das coisas mais fáceis, e a vista ocupa um lugar importante entre os sentidos, conseguiremos o nosso objetivo se colocarmos sob os olhos das criancinhas todas as primeiras noções de história natural, de ótica, de astronomia, de geometria, etc., mesmo segundo a ordem do programa didático, há pouco delineado. Neste livro, com efeito, pode pintar-se montes, vales, plantas, aves, peixes, cavalos, bois, ovelhas, homens de várias idades e de várias estaturas, e principalmente a luz e as trevas, o céu com o sol, a lua, as estrelas, as nuvens, as cores fundamentais, e também os utensílios domésticos e os dos artesãos: panelas, frigideiras, talhas, martelos, tesouras, etc. De igual modo, podem pintar-se pessoas com os seus distintivos, como um rei com o cetro e a coroa, um soldado com as armas, um cocheiro com o coche, um lavrador com a charrua, um carteiro a distribuir cartas, e, em cima de cada figura, uma inscrição a indicar o seu significado: cavalo, boi, cão, árvore etc.

Utilidade deste livro.

26. A utilidade deste livro é tríplice: 1. ajuda a imprimir as coisas na mente das crianças, como dissemos já; 2. atrai os espíritos tenros a procurar em qualquer outro livro coisas para se divertir; 3. faz aprender a ler mais facilmente, pois, como as figuras das coisas têm o seu nome escrito por cima, poderá começar-se a ensinar a ler, ensinando a ler as letras desses nomes. (COMENIUS, 2001, cap. XXVIII).

A extensão dessas citações se justifica porque elas exprimem precisamente o papel atribuído ao livro didático dentro da didática moderna inaugurada por Comenius e como ele deve se constituir graficamente. Assim, Orbis Sensualium Pictus não só receberá uma edição em inglês e latim no ano seguinte à sua edição em alemão, seguida de edições trilíngues e quadrilíngues menos de uma década depois, em países de profissão de fé reformista, como será o modelo para outros livros e precursor de cartilhas e livros com imagens adotados em todo o mundo ocidental. Sua influência pode ser atestada por uma obra editada na França, país católico, totalmente calcada no livro de Comenius. Trata-se de Le miroir de l'art et de la nature, de Nicolas Le Jeune, com o propósito de ensinar latim, francês e alemão, apresentando os conhecimentos gerais abordados por Comenius em imagens e organização visual e tipográfica praticamente idênticas, mas sem mencionar nenhuma referência à obra original (figura 15).

Mas um aspecto ainda a ressaltar é que, dadas as características de integração entre texto e imagem em Orbis sensualium pictus, Comenius certamente se envolveu diretamente com sua concepção gráfica e sua impressão. Seu conhecimento da matéria é tão evidente, que ele a utiliza para estabelecer um paralelo entre a organização da escola e do ensino e a impressão de livros em múltiplos e detalhados aspectos, a partir da nomeação de seu método pedagógico como uma derivação da palavra tipografia. A eloquência e a profundidade com que Comenius relaciona didática, impressão e livros didáticos justifica a extensão de nova citação, em que se omitiram muitas passagens: 
Figura 15 - Nicolas Le Jeune, Sieur de Francqueville. Le miroir de l'art et de la nature. Paris, 1691
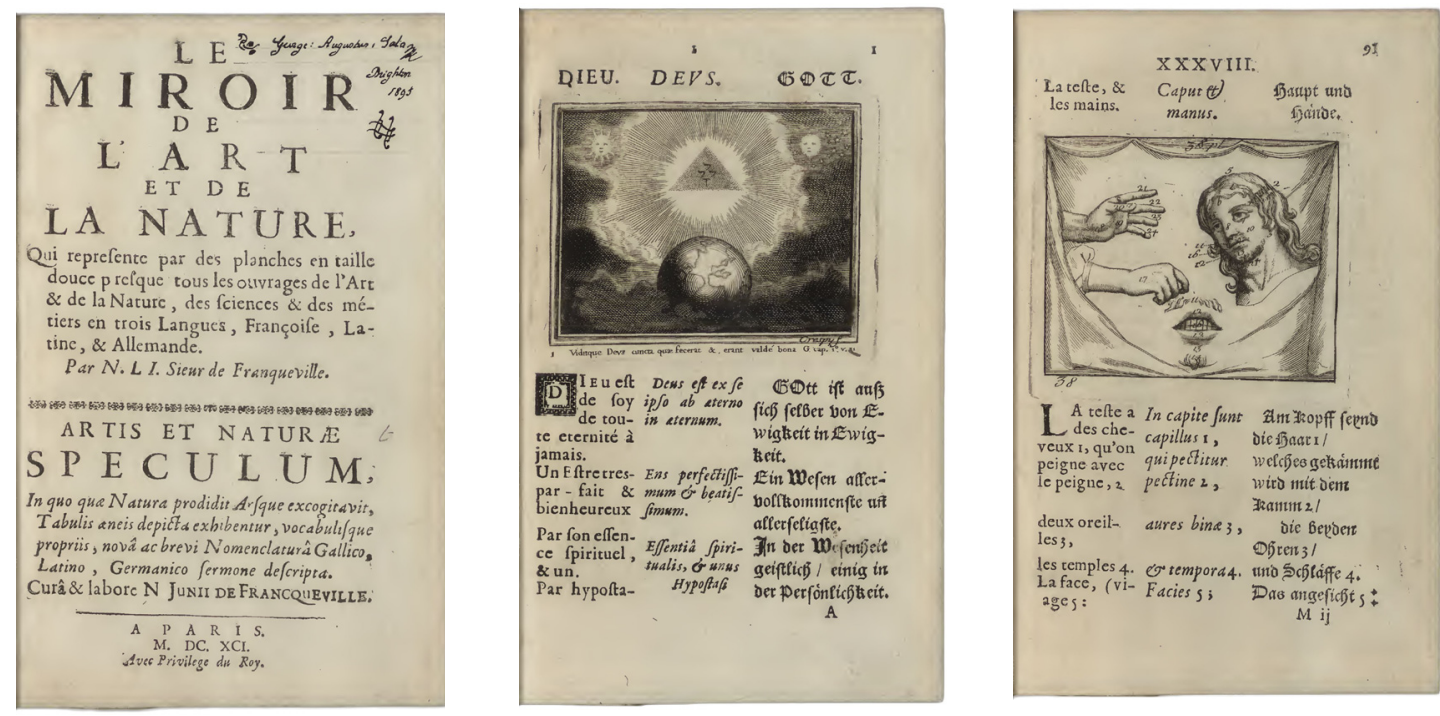

Fonte: Internet Archive/Unesco, Getty Research Institute, 9923864330001551. Public Domain. Reprodução permitida para uso não comercial.

5. Mas retomemos a comparação que fomos buscar à tipografia e utilizemo-la para explicar melhor ainda em que consiste o mecanismo regular do nosso método e para mostrar claramente que é possivel imprimir as ciências no espírito da mesma maneira que, externamente, é possível imprimi-las no papel, com tinta. E que razão haverá para que se não possa forjar um nome susceptível de convir à nossa nova Didática, como o termo didacografia, modelado sobre a palavra tipografia? [...]

6. A arte tipográfica tem os seus materiais e os seus trabalhos. Os materiais principais são: o papel, os tipos, as tintas e o prelo; os trabalhos são: a preparação do papel, a composição, a paginação, colocar tinta nos tipos, a tiragem das folhas, a secagem, a correção das provas, etc., e cada uma destas coisas faz-se de uma maneira especial, e se se faz da maneira prescrita, tudo corre normalmente.

E igualmente da arte didática.

7. Na Didacografia (agrada-me usar esta palavra), as coisas passam-se precisamente da mesma maneira. 0 papel são os alunos, em cujos espíritos devem ser impressos os caracteres das ciências. Os tipos são os livros didáticos e todos os outros instrumentos propositadamente preparados para que, com a sua ajuda, as coisas a aprender se imprimam nas mentes com pouca fadiga. A tinta é a viva voz do professor que transfere o significado das coisas, dos livros para as mentes dos alunos. 0 prelo é a disciplina escolar que a todos dispõe e impele para se embeberem dos ensinamentos. [...]. Relação entre os tipos e os livros didáticos.

9. A analogia entre os tipos metálicos e os nossos livros didáticos (tais como nós queremos) é muito grande. Efetivamente, em primeiro lugar, assim como é necessário fundir, polir e adaptar os tipos, antes de se começar a impressão dos livros, assim também é necessário preparar os instrumentos do novo método, antes de começar a pôr em prática esse novo método. [...]. 
12. Os tipos, para que possam estar sempre à mão para qualquer uso, não se devem deixar espalhados aqui e além, mas devem ser colocados ordenadamente em caixas e em caixotins. Do mesmo modo, os nossos livros, tudo o que nos oferecem para aprendermos, não o devem oferecer de modo confuso, mas repartido do modo mais distinto possivel, em tarefas de um ano, de um mês, de um dia e de uma hora. [...].

13. Retiram-se das caixas apenas os tipos de que temos necessidade para executar determinada obra, deixando-se os outros sem se lhes tocar. Também se devem colocar nas mãos das crianças somente os livros didáticos de que têm necessidade na sua classe, para que os outros não sejam ocasião de distração e de confusão.

14. Finalmente, o tipógrafo serve-se de um componedor para dispor linearmente os caracteres em palavras, as palavras em linhas, as linhas em colunas, para que nada fique fora de proporção. Do mesmo modo, aos educadores da juventude, é necessário dar normas, em conformidade com as quais executem as suas obras, isto é, devem escrever-se para uso deles Livros-roteiros que os aconselhem quanto ao que hão-de fazer, em que lugar e de que modo, para que se não caia em erro. [...].

20. Os livros mais elegantemente impressos têm os capítulos, as colunas e os parágrafos claramente distintos, com certos espaços vazios (requeridos, quer pela necessidade, quer por uma melhor visão), tanto marginais como interlineares. Também o método didático deve necessariamente prescrever períodos de trabalho e períodos de repouso, de determinada duração, para recreações honestas. Efetivamente, esse método prescreve programas para serem desenvolvidos em um ano, em um mês, em um dia e em uma hora [...].

26. Por último, terminada a tiragem do livro, recolhem-se todas as folhas impressas e põem-se em ordem, para que possa ver-se claramente se os exemplares estão completos e íntegros, sem defeitos e em estado de serem expedidos e postos à venda, de serem lidos e utilizados. Isto mesmo farão os exames públicos, no fim do ano, quando os inspetores das escolas verificarem o aproveitamento dos alunos, para constatarem a sua solidez e a sua coesão, que são a prova de que tudo o que devia ser aprendido foi, de fato, completamente aprendido. (COMENIUS, 2001, cap. XXXII).

\section{Caráter referencial das imagens nos livros didáticos}

Esse tipo de obra didática inaugurada por Comenius compartilha com as obras científıcas um avanço propiciado pelo surgimento da impressão relativo à reprodução de imagens, apontado por Elizabeth Eisenstein (1980, p. 100, tradução minha):

Em domínios como anatomia, geografia e astronomia, a influência da impressão indicou sentidos além da ambiguidade de palavras, mediante declarações pictóricas e matemáticas precisas. Ao tornar possível duplicar mapas, quadros, tabelas e gráficos, a impressão revolucionou a comunicação científica. Imagens repetíveis e equações repetíveis tornaram possível contornar a confusão gerada pela tradução de uma língua para outra.

No aspecto específico das imagens, David Olson (1997, p. 222), citando o historiador das ciências George Sarton, para quem "o principal evento separando o período que conhecemos como Renascença da Idade Média foi a dupla invenção da tipografia, para o texto, e da gravura, para as imagens", relaciona o esforço de representar o mundo em 
função dos novos meios e públicos a alguns aspectos centrais do desenvolvimento da estrutura do conhecimento e da maneira de pensar. No caso dos mapas, aponta que antes da impressão não se conseguiu reunir informações encontradas em mapas parciais num único grande mapa abrangente devido à falta de meios confiáveis de reprodução - e à ausência de um quadro matemático/geométrico comum, saliente-se, mas este também só possível a partir da transformação da matemática em uma nova linguagem universal para representação do mundo, o que só foi ocorrer num novo quadro mental possibilitado pela cultura impressa.

0 exemplo mais claro dado por Olson é o da nova iconografia botânica, em que a possibilidade de reprodução fiel de um mesmo original detalhado e preciso - no qual se sobressai a função técnica de representação, em comparação à função meramente estética ou simbólica -, associada com a descrição científica, levou à constituição da Botânica como ciência no século XVIII. Em ambos os casos, o do mapa e o do diagrama,

[...] a informação é substituída pela verossimilhança. Uma figura de livro didático das partes de uma flor não se parece em nada com nenhuma flor real. Contudo, essa flor pintada, uma representação, se torna a entidade conceitual em termos da qual nós percebemos e classificamos as flores reais. (OLSON, 1997, p. 242).

\section{Considerações finais}

Um primeiro aspecto que pode ser apreendido da trajetória apresentada - antecipado em Os elementos, de Euclides, ainda timidamente indicado nas obras ramistas e finalmente concretizado pela presença de imagens em Orbis Sensualium Pictus e seus sucessores - é o caráter multimodal do conteúdo veiculado por parte considerável dos livros didáticos, a partir da presença de duas linguagens, a verbal e a visual, e sua interação para a produção de informação e sentido. Embora essa interação tenha sido preconizada conscientemente pelo próprio Comenius, obviamente não foi feita com a utilização de um termo e com o alcance de significado que só seriam possíveis três séculos mais tarde.

Um segundo aspecto, concernente às relações entre livro didático e cultura da impressão que ampliariam o próprio significado do conceito de alfabetização, é apontado também por Michael Twyman (1986, p. 190, tradução minha), ao referir-se ao fato de que:

Alfabetização, em todos os níveis - seja no nível acadêmico, administrativo, industrial ou empresarial, em uma extremidade do espectro, ou da criança ou adulto marginalmente alfabetizados, no outro -, certamente deve ser interpretada como mais do que a compreensão de como ler e escrever prosa contínua [...]. Nossa visão convencional de alfabetização também não leva em conta os métodos gráficos muito mais sutis de articulação de linguagem de que comumente fazemos uso quando criamos linguagem (pela escrita, pela impressão e pela digitação) e quando lemos. Refiro-me ao uso de alfabetos variantes, tais como versais para complementar letras minúsculas, e itálicos e negritos, que acompanham as letras de peso normal. 
Ou seja, mais do que a alfabetização em sentido estrito, a leitura da forma impressa, tanto nos livros didáticos produzidos imediatamente à virada instrucional como nos livros didáticos do mundo de hoje, envolve também uma alfabetização gráfica, uma iniciação nos códigos estabelecidos pela tipografia e pelo desenho da página impressa, o que definitivamente liga o livro didático à cultura da impressão estabelecida pela invenção dos tipos móveis e todo o seu desenvolvimento posterior.

Um terceiro aspecto que pode ser apontado diz respeito a uma possível ampliação da definição de livro didático, que poderia ser experimentada como decorrência dos indícios visuais e gráficos trazidos pela amostragem de livros apresentada - em que se reconheceu que uma materialidade e uma visualidade específicas vão se delineando como próprias desse gênero e que um caráter multimodal de seu conteúdo vai se tornando cada vez mais presente. Realizar tal tarefa dependeria de uma ampliação da amostragem iconográfica e do arcabouço conceitual que estenderia e mudaria o foco deste artigo. No entanto, é factível registrar a possibilidade de uma atualização e de uma precisão do conceito de livro didático pela incorporação de outros aspectos ainda não considerados, relativos à sua materialidade, à sua visualidade e à sua linguagem, principalmente visando à compreensão do livro didático produzido contemporaneamente.

Por fim, o exame aqui feito das transformações na materialidade e na organização visual dos conteúdos veiculados pelos meios manuscritos e impressos em função das transformações das demandas educacionais, das possibilidades tecnológicas que caracterizaram o período da virada instrucional e da introdução da impressão tipográfica indica a validade de abordagem semelhante para o período atual, em que novos suportes e novos meios de fluxo de informações decorrentes das tecnologias digitais vêm sendo introduzidos na escola e na educação. Se não há ainda uma visão consolidada e conclusiva sobre o conteúdo e o alcance que a disseminação desses novos meios traz para a educação - disseminação de resto bastante recente e desigual, conforme os países e as regiões, sendo que em nenhum deles se excluiu a utilização do livro didático impresso -, comparações e analogias entre os dois períodos de transformações podem constituir uma aproximação válida ao problema.

\section{Referências}

BITTENCOURT, Circe Maria Fernandes. Livro didático e conhecimento histórico: uma história do saber escolar. 1993. Tese (Doutorado) - Faculdade de Filosofia, Letras e Ciências Humanas, Universidade de São Paulo, São Paulo, 1993.

COMENIUS, Iohannis Amos. Didactica magna. Lisboa: Fundação Calouste Gulbenkian, 2001.

EISENSTEIN, Elizabeth Lewisohn. Literacy and the future of printing: the emergence of print culture in the West. Journal of Communication, Oxford, v. 30, n. 1, p. 99-106, 1980.

HAMILTON, David. What is a texbook? Paradigm - Journal of the Textbook Colloquium, Champaign, n. 3 , jul. 1990. Disponível em: <http://faculty.education.illinois.edu/westbury/paradigm/hamilton.html>. Acesso em: 20 jan. 2017. 
HAMILTON, David. Instruction in the making: Peter Ramus and the beginning of modern schooling. In: ANNUAL CONVENTION OF THE AMERICAN EDUCATIONAL RESEARCH ASSOCIATION, 2003, Chicago. Anais... Chicago, 2003. Disponivel em: <http://www.leeds.ac.uk/educol/documents/152133.htm>. Acesso em: 05 jun. 2017.

HONEYCUTT, Lee. The history of Quintilian's text. In: QUINTILIAN'S Institute of Oratory. [S. I.: s. n.], 2007. Disponível em: <http://rhetoric.eserver.org/quintilian/history.html>. Acesso em: 28 jan. 2017.

LAJOLO, Marisa; ZILBERMAN, Regina. A formação da leitura no Brasil. São Paulo: Ática, 1999.

LOBEL, Edgar. The greek manuscripts of Aristotle's Poetics. Whitefish: Kessinger, 2006.

MARTINS, Wilson. A palavra escrita: história do livro, da imprensa e da biblioteca. São Paulo: Ática, 2002.

OLSON, David. Richard. 0 mundo no papel: as implicações conceituais e cognitivas da leitura e da escrita. Tradução de Sérgio Bath. São Paulo: Ática, 1997.

ONG, Walter Jackson. Ramus: method, and the decay of dialogue. Cambridge: Harvard University, 1983.

ONG, Walter Jackson. Orality and literacy: the technologizing of the word. London; New York: Routledge, 2002.

SILVA, Libanio da. Manual do typographo. Rio de Janeiro: Francisco Alves, 1922.

TWYMAN, Michael. Articulating graphic language: a historical perspective. In: WROLSTAD, Merald E.; FISCHER, Dennis F. (Ed.). Toward a new understanding of literacy. New York: Praeger, 1986. p. 188-251.

TWYMAN, Michael. Textbook design: chronological tables and the use of typographic cueing. Paradigm Journal of the Textbook Colloquium, Champaign, n. 4, Dez. 1990. Disponível em: <http://faculty.education. illinois.edu/westbury/paradigm/twyman.html>. Acesso em: 05 jun. 2018.

VINCENT, Guy; LAHIRE, Bernard; THIN, Daniel. Sobre a história e a teoria da forma escolar. Educação em Revista, Belo Horizonte, n. 33, p. 7-47, jun. 2001.

\section{Obras com páginas reproduzidas nas figuras:}

ARISTÓTELES. De arte poetica. Florença: Petro Victorio, 1564.

ARISTÓTELES; Castelvetro; LODOVICO. La poetica d’Aristotile. Basilea: Pietro de Sedabonis, 1576.

COMENIUS, Johann Amos. Orbis sensualium pictus. Nuremberg: [s. n.], 1664.

DONATUS, Aelius. Ars minor. [S. I.: s. n., 1475?].

DONATUS, Aelius. Ars minor. Augsburg: [s. n.], 1497. 
EUCLIDES. Elementa: códice do século XIII. [S. I.: s. n., sec. XIII].

EUCLIDES. Elementa, liber 1. Argentoratum (Strasbourg): [s. n., 1538.].

EUCLIDES; BYRNE, Oliver. The first six books of the elements of Euclid. London: William Pickering, 1847.

QUINTILIANUS, Marcus Fabius. De institutione oratoria: manuscrito. Nápoles: [s. n.], 1482.

QUINTILIANUS, Marcus Fabius. Oratoriarum institutionum libri duodecim. [S. I.: s. n.], 1516.

RAMUS, Petrus. Grammatica graeca quatenus a lat. differt. Paris: André Vechel, 1560.

RAMUS, Petrus. Arithmetica. Paris: André Vechel, 1562.

RAMUS, Petrus. Grammaire. Paris: André Vechel, 1572.

RAMUS, Petrus. Professio Regia: Septem artes liberales... Basilea: Sebastian Henchipetel, 1576.

Recebido em: 04.02.2017

Revisões em: 07.06.2017

Aprovado em: 08.08.2017

Didier Dominique Cerqueira Dias de Moraes é designer gráfico especializado em livros escolares. Tem mestrado pela Faculdade de Educação da Universidade de São Paulo e doutorado pela Faculdade de Arquitetura e Urbanismo da mesma universidade, com pesquisas sobre visualidade do livro didático brasileiro. Autor de Design de capas do livro didático: $A$ Editora Ática nos anos 1970 e 1980. São Paulo: Edusp, 2017. 